\title{
How the World Economy revolves round Entrepreneurial University Model: Cases from India
}

\author{
(C) Mr. Samrat Ray \\ Alagappa University, India
}

\begin{abstract}
Academic capitalism is quite different in perspective when speaking about the triple helix model or the entrepreneurial dimensions of University-Industry-academic nexus which gained prominence quite late in few countries as other so called developed countries had such a build up quite early when it left the gilded innovation structure to a more liberal perspective of academics and knowledge management. Research has shown that crisis and disasters have made innovation thoughts easier with greater transition potential across borders in the form of tacit knowledge via trade exchanges. Previously earlier to the 1980s emerging or the underdeveloped countries rarely witnessed autonomy in state owned academic institutions where universities were merely a place for teaching. With greater liberalization and moving towards free markets, emerging economies like India realized the importance of autonomy in institutions and got rid of the license raj which was destroying the foundations of economy. This paper scrutinizes the research gap in Entrepreneurial university concept applications in India firstly which can be applied to other developing countries were the nexus between industry and academic pursuits are gaining momentum and very little literature is available which can put forth policy grounds for government and national agenda holders to create sustainable paths leading to successful innovation products which can contribute to economic growth and development of society at large. The paper primarily is build on case studies which analyses and answers global thoughts hovered around Why Academic Capitalism was late in developing countries? Can the world too learn from Triple Helix applied to innovation system nationally in relatively poor country like India which is still a agrarian economy at large?
\end{abstract}

Keywords: Entrepreneurial University, Triple Helix Model, National Economy, India, Economic Policy.

Introduction: The modern day definition of how we perceive and utilize knowledge has grossly changed over few decades. Recent advances in technology and science has made it necessary for the cradle of knowledge to transgress higher altitudes and effectual knowledge for betterment of society. Knowledge in the context of historical flora and fauna has changed in it structural and functional domain with better utilization indexes and an urge to deliver beyond broken promises. There was comprehensive promises to adapt to regional dialects and practices in early stage knowledge in emerging countries which with improvements in logistical sources made it possible for increased utilization and advancement in research oriented universities in countries like India [20]. Scientific discourses have long been at the backstage of global innovation wherein research and educational processes have seen close cooperation with development and growth of society at large. While the west saw a rapid growth in human development which was a target for knowledge base for decades saw a drastic channelization of close cooperation of industry-education nexus during various crisis points from the Great Depression to FDR policies in USA [11] when Keynesian thought process was highly accepted into national policy making [19]. Post Keynesian development saw the birth of neo classical dialects with greater monetary policy inclination and liberal thoughts related to functioning of the Federal bank structure in USA. Wherein post the Great Depression there was greater intervention of the government with an influx of stimulus to create demand, few liberal thinkers like Hayek championed the cause of free markets with lower intervention from the government structure and bureaucracy. But nevertheless, academic capitalism was a process of countervailing power nexus which was not a distant dream for even the free movers and thinkers 
from the Austrian School of Economics. Economic fluctuations have seen a drastic change in facts and figures during past pandemics like Ebola, Spanish or the Russian Flu which was accountable for mass deaths and great loss in economic and industrial tradeoffs. There is of course a definitive change and differential treatment of the way the present pandemic has cast a deep shadow over economic velocity globally with the flattening of curves to a sudden $\mathrm{V}$ or $\mathrm{K}$ shaped economic recovery [12]. There is not withstanding proposition to point out that innovation in healthcare as well as traditional economics as studied in universities did not quite suit to the crisis as policy makers rushed worldwide when WHO declared the pandemic as a situation of international importance [21]. Knowledge spillovers are born out of the novel concept of knowledge spillover theory of entrepreneurship which catalyzes the belief of regionalization of knowledge which can boost entrepreneurship at large. The Indian government has for quite a time long now has changed its internationalization policy by bringing in health tourism as well as its ambit of health research which has been regionalized as per requirements. Audretsch (1995) states the exogenous character of knowledge spillover as knowledge as indicators of economic agents are seekers endogenously. Rees accordingly states the viability of the birth of newer firms which rely more on knowledge spillovers than the matured ones which don't match the functionality. Ceteris Paribus, greater educating graduates from higher institutions of learning will tend to create more incubation and start ups in regional proximity as tacit knowledge in natural sciences are larger than codified counterparts. Zucker (1998) suggests that it is not merely the influences of knowledge spillovers but the quality and quantity of great research workers who can in fact influence the new incubation process and industry interactions. Such notions are little bit true as the star scientists born out of the research labs in institutes like MIT and Bell labs has shown the same regarding firm creation while we land on to the concept of Silicon Valley model of innovation. In this regards Shane has shown the determinant policy of closeness of MIT to creative zones and economic outputs. The research activity in institutions of higher learning has been analyzed empiri- cally by Henderson as well as Jaffe which researches over number of academic journals, literature, patenting which has positive correlation with knowledge spillovers [13]. Harris (2001) has challenged the compensation and benefits of universities arising out of academic capitalism at large. The notion of direct commercial benefits to universities due to spillovers is negligible which has also been proved by Marshall when he quoted in favor of economic knowledge arising with a grain of surprise. Sarasvathy et al. has clarified the rise of ideas and action based studies which creates markets as well as products. Such notion if applied to the interaction has propounded the spillover which can be economically also beneficial to the university [14]. As Professor Spivak of Columbia university in her works have quoted the "Subaltern" it is necessary to dive deep into academic history and commercial studies relating to historical dialects of economics. To understand academic capitalism in emerging country like India it is necessary to understand its colonial history and how post colonialism it suffered from lack of fresh thoughts [2]. The higher educational institutes in India were mostly governed by age old British practices of knowledge management with births of state universities under the presidency of Calcutta, Bombay and Madras which became a hot breeding ground for inequality with rise of elites as they imbibed cultures not patriotic in beliefs. So definitely these institutions were merely deaf and dumb to innovation were teaching was the main goal. This in fact was reversed little bit with the birth of new India releasing its cage of bureaucratic hurdles and license raj which has for decades paralyzed the economy of India. Whereas the post depression years in the USA saw a move towards greater demand creation, the war years saw the birth of industry nexus with academics to foster war efforts and build on technology. The cold war years saw Soviet policy governing birth of space program and nuclear technology meeting war efforts requiring more sophistication in research activity which was mostly state run apparatus were as in USA capitalism was bearing a misnomer [3]. With the fall of Soviet policies saw a push towards capitalism globally and the birth of academic commercialization thereafter. Training the economic history of India saw the birth of late 
Nehru thoughts when the institutes were granted autonomy for research and development [1]. The rise of autonomy in institutes of national importance like IITs, IIMs, and IISC in India saw birth of new ideas and globalization post the liberal policy years of 1991 in India when India decided to open its ambit of economic activity to globalization and free market policy gained momentum. From that time on the birth of newer patenting, educational policy and incubation mechanism as well as new biotechnology related incubation gained momentum in Indian universities. Romer and Krugman (1986) has instigated new model where spillovers occur from knowledge institutions to firms in regional proximity. Such beliefs are fastened by great number of literature available in this area (Audretsch and Stephan) [15].Porter (2001) further argues over competitive advantage philosophy of firms which are beneficiary of knowledge spillovers from universities which account for greater economic welfare. Sustainability in competitive advantage arena regarding resources and availability of knowledge has been quoted also by Alvarez. Putman (2001) generates the idea of social capital which is more beneficial contrary to neoclassical economic beliefs challenging the existence of physical capital (16). Social capital has been the relationship diversity among social groups and organizations and is doomed to play critical role in it. Scarpetta et al. (2002) introduced the "Churning" concept in entrepreneurial university by bringing in few concepts at foundation level [17]:

1. The smaller firms account for greater growth parameters.

2. The more young the firm is the more growth rate it imbibes.

3. Survival is less for young firms.

Further a hypothesis is generated for localization which states and brings forth spatial concept with near proximity of knowledge creating bases [4]. A contradictory hypothesis has also been generated regarding entrepreneurial financing as is stated to rely more on venture capitalism rather than debt financing which holds little or no truth regarding India where bigger pie of the population is in informal sector and lending is a traditional practice. We also come across the concept of "Jugaad" in Indian business sutra. The Galbraith years in USA saw 2 countervailing policies in state architecture of policy regarding academicians and the systematic rise of knowledge management. According to Etzkowitz, entrepreneurial university highlights the birth of capitalization of knowledge wherein knowledge is taken as an economic indicator. Clark (1998) brought forward innovative idea generation, newer student bodies reflected in the entrepreneurial spirits. Clark also stated the "Stand up" factor of the entrepreneurial university. Such factorization greatly is propounded in the vaccine production drive of Indian government and its policy. Gibb (2012) stated entrepreneurial university in line with employability, mission and vision addressing the varied problems of society and economics. Etzkowitz and Leydesdorff had stated and propounded the Triple Helix Model of three distinct union of university [5], government and university for bringing out various functionaries of knowledge based economies at large. Historically the Morill Act has started the applicability of knowledge towards improvements in society. In entrepreneurship body building another important model is Timmons Model of Entrepreneurship which relies heavily on resource management and opportunity creation wherein Indian policy management at government level to contain the virus has been cleverly managed with greater resource allocation. The policy is very grounded over practical models of nexus building.

Materials and Methods: The research work utilizes exploratory case study from national institution in India with unstructured interviews often to create relation and understand diversity in response mechanism. The qualitative databases and other documents were feeded in the software package of Atlas. ti. The reason behind use of this particular software was to create coding and better structuring of utility based documents from our study.

Case Study:

Serum Institute of India: The reason for choosing such a case study arises out of the recent success story of India regarding its championing cause towards creating World's largest vaccination drive and plunging from a import based sector to a grossly export maker of vaccines even to developed economies. At a time when India was 
struggling and lagging behind the take off stage of innovation in healthcare fighting in Covid the government adopted the entrepreneurial university model wherein individual players were granted exclusive liberty in policy making and $\mathrm{re}^{3}$ search activity highlighting concepts and flavor of Triple Helix Model circumscribing other local factors of politics and corruption to create a resilient body of values. It imbibed in its philosophy of Made in India wherein Vaccines were created in collaboration with advanced technology transfer and national research agenda. The institute runs on great philanthropic agenda and has become the number one biotechnology company in India with great capacity of vaccine development and inoculation which is accredited by the World Health Organisation too. The institute is also credited with a modern biotechnology park of its kind. The WHO led strategic body granted recently emergency use license to the Serum Institute of India vaccine and AstraZeneca Vaccine for mass usage over 18 years of age. Thereafter the institute will collaborate with AstraZeneca to produce the Covax vaccine and will reach to distant countries affected by the virus which is in its scientific goals [6]. University of Oxford has been with its spinoff Vaccitech to produce the AstraZeneca vaccine.

Key Takeaways:

1. University-Industry-Government played critical role in the Indian government vaccination drive.

2. Entrepreneurial finance was spearheaded by knowledge proximity.

3. Emerging economy like India developed Triple Helix out of crisis to be a model for other developing economies.

4. The run from red tapes to free economy with global trades were born out of Triple Helix Model.

5. The underlying principle of greater social improvements and new channel creation which was stated by Erzkowitz has been greatly adapted.

6. Timmons model of entrepreneurship is very much portrayed here with a opportunity driven innovation with successive bootstrapping for future novel ideas [22].

The interview of personnel from government also highlighted the grants and funding procedure for logistics and vaccine delivery. It also high- lighted the utility of finance and better research outlook if government plays an independent role in policy making. Few abstract respondents were selected according to Bogdan (2011) to understand the fluctuations in interviewee responses regarding knowledge spillovers. Foreign direct involvement was quoted rather than FDI which was modeled exclusively to better understand the globalization and technology transfer mechanism [7]. Rest lay emphasis on vaccine logistics which nearly lay claim to spillover theory.

Deduction: In the context of World Economy and how governments have changed its perception of globalization has challenged more often the concept of "The World is flat". The idea and constitutional powers of the IMF as well as the World Bank has been challenged regarding its activity where the "Will the Subaltern ever Speak" is addressed regarding global poverty reduction, climate change, Global inequality and Literacy measures which has for long crippled the global economy. Even great scholars like Spivak has dealt the subaltern and its activities at grassroot levels which are mandatory to analyse while deciphering the role played by national governments in poor countries where technological history has been crippled by colonial structures. Even the research done with technological output gains momentum through historical materialism which even Marx has propounded during his discourses in The Communist Manifesto and in dealing with his book "Capital". In a vastly poor country, any form of innovation born out of advanced research environmental impact often is a misnomer as agriculture; hunger and illiteracy are great sins which they still imbibe in their culture. So challenging historical dialects and cultural ecology often becomes greatly impossible and bringing in rapid changes in the business ecosystem via strategy according to Porter is always a dead bed. The World Bank is fighting since the time of McNamara to eradicate poverty through various agenda. The recent SDGs proclaim more promises than reality which when addressed through field experiments create inequality [8]. In such a scenario, the case study and interviews done with the premier private organization which has governmental intervention at large in spearheading the vaccine development process shows the disruption in innovation and 
policy making which can be a classic example of entrepreneurship, innovation and regressive models of business operations. The various literature availed and groundwork done in doing unstructured interviews among doctors, researchers and other healthcare workers in the institute proves the validity of the Triple Helix Model in Indian context [10].

Conclusion: There are myriad beliefs and great complexity in the way research is performed still in public institutions that are comparatively better even in sub Saharan countries compared to Indian subcontinent [18]. The Triple Helix Model that was applied as part of national innovation structure by the central government in vaccination drive and in its fight towards COVID19 greatly champions the cause of the model utility in emerging economies were corruption and free markets still are a distant dream. Though a lot of research work has been done in analysing the inter regional effects among the helixes and the buildup of an extra helix or two or N- Helix model of innovation (9), further gaps arise when bringing in corruption, rate of literacy and internationalization policy in national government agenda. The concept of corruption can always hamper the mingling of the helixes at large as knowledge brings forth ethical concerns where the Laissez Faire economics can bring in further destruction in policy developments. The Indian case definitely was born out of the crisis when it shifted its agenda from being an importer for healthcare products for its billion populations to being an exporter at large which has been indeed a landmark achievement when advanced countries like Germany and USA were bowed down by rising curves in corona virus deaths. As Loyt has suggested a buildup of an extra helix to counter politics it is in fact a research to watch out for regarding indicators like corruption, literacy and awareness programs which are hindrances towards demand push and technology pull. What should be a government doing rather than planning? Can we move towards a Keynesian approach to Triple Helix or the helix will meltdown at the face of Austrian Economic Thoughts of free markets? What can corruption do to the entrepreneurial structure? Are we guarding our thoughts? These are the major fallouts and hindrances which future academicians needs to address at large. Such thoughts can be best understood with starting from exploratory studies with blindfold judgments at large. Economic variability, geographical hindrances and cultural pursuits bring forth multidisciplinary approaches to solving the academic capitalism mirage in emerging context which when paralleled with countries like USA where land grant university played a good role in advancing the cause of academic utility with birth of new public players who can foster future researches.

Future Research Implications: This research builds on a decade long literature available globally with applications at national level that in India has been a gross success for government planning boosting its foreign policy agenda and economic policy at large. The research work addresses the research gap of application of Triple Helix model in emerging economy like India which can be a ready to refer literature for future researchers to think experiment and utilize for laying down ideas for economic expansion, global economic problems, and commercialization of knowledge, technology transfers and patenting industry.

\section{REFERENCES}

1. Etzkowitz, H. and Leydesdorff, L. (1995). The Triple Helix: university -industry - government relations. A laboratory for knowledge based economic development. EASST Review. European Society for the Study of Science and Technology, 14 (1): 18-36.

2. Agrawal,A., (2001) University-to-industry knowledge transfer: literature review and unanswered questions. International Journal of Management Reviews, Vol. 3, Issue 4, pp. 286-300

3. Altbach, P. G. (2005). Globalization and the University: Myths and Realities in an Unequal World. EPI, 2005. Global Higher Education Rankings. Affordability and Accessibility in Comparative Perspective. Washington: EPI, www. educationalpolicy. org. 
4. Stake, R. E. (1995). The art of case study research. SAGE Publications.

5. Birley, S. (2004). "Universities, Academics, and Spinout Companies: Lessons from the Imperial". International Journal of Entrepreneurship Education, 2 (1): 123-53.

6. Coaldrake, P. (2001) 'Responding to Changing Student Expectations' Higher Education Management. Vol. 13. No. 2. Pp72-94 OECD

7. Etzkowitz, H., (2004). 'The evolution of the entrepreneurial university'. Int. J. Technology and Globalization, Vol. 1, No. 1, pp. 64-77.

8. Etzkowitz, H. (2003) 'Research groups as 'quasi-firms': the invention of the entrepreneurial university’. Research Policy 32, pp. 110-121.

9. “Can the Subaltern Speak?" In Marxism and the Interpretation of Culture, ed. Cary Nelson and Lawrence Grossberg. Urbana: University of Illinois Press, 1988, 271-313.

10. Kinga Bednarzewska, 2016. "University-Business-Government the Triple Helix Model of Innovation," Managing Innovation and Diversity in Knowledge Society Through Turbulent Time: Proceedings of the Make Learn and TIIM Joint International Conference 2016, ToKnowPress.

11. Galvao, A., Mascarenhas, C., Marques, C., Ferreira, J. and Ratten, V. (2019), "Triple helix and its evolution: a systematic literature review", Journal of Science and Technology Policy Management, Vol. 10 No. 3, pp. 812-833. https://doi. org/10.1108/JSTPM-10-2018-0103.

12. Cai, Y. Implementing the Triple Helix model in a non-Western context: an institutional logics perspective. Triple Helix 1, 1 (2014). https://doi. org/10.1186/s40604-014-0001-2.

13. Denzin NK, Lincoln YS: Introduction: The Discipline and Practice of Qualitative Research. Collecting and Interpreting Qualitative Materials. Edited by: Denzin NK, Lincoln YS. 2003, SAGE Publications, Thousand Oaks, London, New Delhi, 1-45.

14. Quartey, S. H., Oguntoye, O. Understanding and Promoting Industrial Sustainability in Africa Through the Triple Helix Approach: a Conceptual Model and Research Propositions. J Knowl Econ (2020). https://doi. org/10.1007/s13132-020-00660-2

15. Shenoy, M. (2016). Industrial ecology in developing countries. In R. Clift \& A. Druckman (Eds.), Taking stock of industrial ecology (pp. 229-245). Switzerland: Springer Cham.

16. Sampath, P. G., \& Ayitey, D. (2016). External opportunities, innovation and industrial growth: The case of GVCs in Africa. In: Sampath P.G., Oyelaran-Oyeyinka B. (Eds.), Sustainable industrialization in Africa. London: Palgrave Macmillan.

17. Bo Carlsson \& Zoltán J. Ács \& David B. Audretsch \& Pontus Braunerhjelm (2015) "Knowledge creation, entrepreneurship, and economic growth: a historical review," Chapters, in: Global Entrepreneurship, Institutions and Incentives, chapter 5, pages 71-107, Edward Elgar Publishing.

18. Savetpanuvong, P. and Pankasem, P. (2014) "Entrepreneurial University model: A theoretical perspectives on strategy, entrepreneurship, and innovation," 2014 IEEE International Conference on Management of Innovation and Technology, Singapore, pp. 242-247, doi: 10.1109/ICMIT. 2014.6942432.

19. Audretsch, D. (2007). The entrepreneurial society. Oxford: Oxford University Press.

20. Audretsch, D. B., Lehmann, E., \& Warning, S. (2005). University spillovers and new firm location. Research Policy, 34 (7), 110-1112.

21. Clark, B. R. (1998). Creating entrepreneurial universities. Oxford: Pergamon.

22. Verencia Winona Janice, Melia Famiola, (2018) “Perceived Risks in Entrepreneurial Process among Culinary SMEs “, International Journal of Management and Applied Science (IJMAS), pp. 21-27, Volume-4, Issue-11 